\title{
STERNOCLEIDOMASTOID-CLAVICLE MYOOSSEUS FLAP IN PATIENT WITH PLATE DISPLACEMENT POST RESECTION AND RECONSTRUCTION OF AMELOBLASTOMA
}

\author{
Ronald Natawidjaja ${ }^{1}$, Gede Budhi Setiawan ${ }^{2}$ \\ ${ }^{1}$ General Surgery Training Programme, Faculty of Medicine Udayana University, Sanglah General Hospital \\ Denpasar, Bali, Indonesia. Correspondence: ronaldnatawijaya@yahoo.com. \\ ${ }^{2}$ Division of Surgical Oncology, Department of Surgery, Faculty of Medicine Udayana University, Sanglah \\ General Hospital Denpasar, Bali, Indonesia.
}

\begin{abstract}
Background: ameloblastoma is a common tumor found in head and neck disorder. The definitive treatment include resection of tumor and reconstruction for filling the large defect which left after tumor resection. The reconstruction option which can be done is flap method. In this case, we used sternocleidomastoid-clavicle myoosseus flap in our patient with post traumatic plate displacement post resection and reconstruction of ameloblastoma. Case: a 22-year-old woman presented with unstability of jaw after hitting her chin to the table since 3 days prior to admission. On 2011, she had history of ameloblastoma which got resected and reconstructed with fibular graft and plate in the same year. While the plate seemed to be broken, she was managed with plate removal and reconstruct with sternocleidomastoid-clavicle myoosseus flap. Post operation, patient managed with gradual diet from liquid to solid. Observation Post Operation Day (POD) 3, flap is vital. Patient is discharged on POD 7 and visit as outpatient every 3-5 days until POD 14. Finally, we remove the suture, operation scar is good, and the flap is vital during one year follow up. Conclusion: sternocleidomastoid-clavicle myoosseus flap is practical and safe procedure, which can be used as alternative option in mandible reconstruction.
\end{abstract}

Keywords: reconstruction, flap, sternocleidomastoid-clavicle, ameloblastoma.

\section{FLAP MYOOSSEUS STERNOKLEIDOMASTOID-KLAVIKULA PADA PASIEN DENGAN PLATE DISPLACEMENT PASKA RESEKSI DAN REKONSTRUKSI AMELOBLASTOMA}

\author{
Ronald Natawidjaja1, Gede Budhi Setiawan ${ }^{2}$ \\ ${ }^{1}$ Program Studi Ilmu Bedah, Fakultas Kedokteran Universitas Udayana, RSUP Sanglah Denpasar, Bali, \\ Indonesia. Korespondensi: ronaldnatawijaya@yahoo.com \\ ${ }^{2}$ Divisi Bedah Onkologi, Departemen Ilmu Bedah, Fakultas Kedokteran Universitas Udayana, RSUP Sanglah \\ Denpasar, Bali, Indonesia.
}

\begin{abstract}
ABSTRAK
Latar belakang: ameloblastoma merupakan tumor yang seringkali ditemukan pada kelainan kepala dan leher. Penanganan definitif dilakukan dengan tindakan pembedahan reseksi tumor dan rekonstruksi mengingat defek yang akan ditinggalkan cukup besar paska reseksi tumor. Salah satu teknik rekonstruksi yang dapat dilakukan adalah dengan penggunaan metode flap. Pada kasus ini, kami menggunakan pendekatan flap myoosseus sternokleidomastoid-klavikula pada pasien paska reseksi-rekonstruksi ameloblastoma dengan pergeseran plat paska trauma. Kasus: seorang wanita usia 22 tahun, datang dengan keluhan rahang bawah bergerak tidak stabil setelah dagu terbentur ujung meja 3 hari sebelum masuk rumah sakit. Sebelumnya, pasien memiliki riwayat 5 tahun yang lalu
\end{abstract}


terdapat ameloblastoma, kemudian dilakukan reseksi-rekonstruksi dengan fibular graft dan plat pada tahun yang sama. Pada penanganan kali ini, pasien dilakukan tindakan aff plate dan rekonstruksi dengan flap myoosseus sternokleidomastoid-klavikula. Pasien kemudian dipasang drain pada tempat operasi. Paska operasi, pasien diberikan diet bertahap. Pada observasi hari ke-3 paska operasi, flap tampak vital. Pasien kemudian diperbolehkan untuk rawat jalan pada hari ke-7 paska operasi. Pasien kontrol setiap 3-5 hari hingga hari ke-14 paska operasi dan dilakukan lepas jahitan. Luka operasi baik dan flap tampak vital pada evaluasi setahun paska operasi. Simpulan: flap myoosseus sternokleidomastoid dengan menggunakan tulang klavikula merupakan salah satu alternatif pilihan yang praktis dan aman dalam penanganan tindakan rekonstruksi mandibula.

Kata kunci: rekonstruksi, flap, sternokleidomastoid-klavikula, ameloblastoma.

\section{INTRODUCTION}

Mandibular tumor is a common tumor found in head and neck disorder. ${ }^{1-4}$ Mandibular tumor may be odontogenic or nonodontogenic. $^{4,5}$ Odontogenic tumor is normally classified by their presumed of origin, being epithelial, mesenchymal, or mixed lesion. ${ }^{4}$ Odontogenic tumor can be divided into lesion with mineralization and lesion without mineralization. ${ }^{6}$ Odontogenic tumor without mineralization include ameloblastomas, odontogenic keratocysts, and dentigerous cysts. Odontogenic tumor with mineralization include odontomas. ${ }^{6}$ The definitive treatment for nearly all of these kind of mandibular tumor include resection of tumor and reconstruction for filling the large defect which left after tumor resection. Options for treating this mandibular defect include performing no reconstruction with primary closure of the oral soft tissues to themselves, reconstruction with metal plates, nonvascularized bone grafts, and flaps.

Flaps can be classified by its complexity, such as local flaps, regional flaps, and distant flaps. Local flaps are created by freeing a layer of tissue and then stretching the freed layer to fill a defect. In regional flap or pedicle flap, the freed tissue "island" is moved over or underneath normal tissue to reach the defect to be filled, with the blood supply still connected to the donor site via a pedicle. Distant flaps or free flaps are used when the donor site is far from the defect. It has the blood supply cut and then reattached micro-surgically to a new blood supply at the recipient site. ${ }^{1-4}$ In this case, we use regional sternocleiodomastoidclavicle myoosseus pedicle flap to our patient with post traumatic plate displacement post resection and reconstruction of ameloblastoma.

\section{CASE}

A 22-year-old woman, presented with unstablity of jaws after hitting her chin to the table since 3 days prior to admission. On 2011, patient had a history of ameloblastoma which got resected and reconstructed with fibular graft and plate in the same year. The fibular bone was taken from her left lower extremity. She did not take any chemotherapy and radiotherapy after previous operation.

While the plate was seemed to be broken, (figure 1), she was managed with plate removal, and reconstructed using sternocleidomastoid-clavicle myoosseus flap. During operation, she was intubated via nasoendotracheal tube. Incision was done over the old scar in submandibular until angle of mandible. We found that the plate was broken in medial of mandible (figure 2B). An incision was made over left clavicle. We took the anterior part of 
medial third of left clavicle with fan boor (figure 3B). The left sternocleidomastoid muscle was separated from nearby tissue and flapped partially with the clavicle (figure 4). The, the plate was placed in both left clavicle and mandible (figure 5). The wound was closed layer by layer with drain installed.
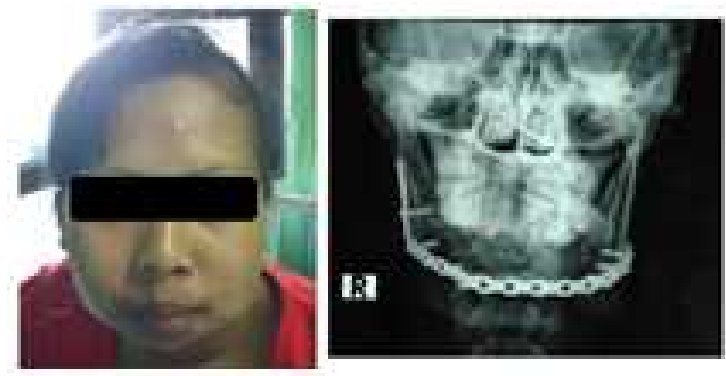

Figure 1. Clinical picture before the operation.

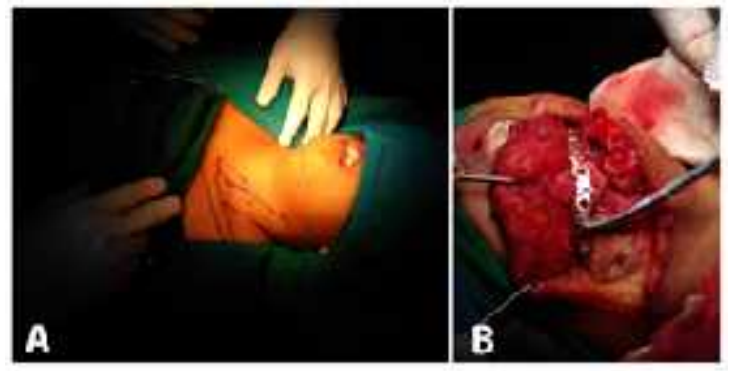

Figure 2. Marking of sternocleidomastoid and clavicule (A), broken plate (B).

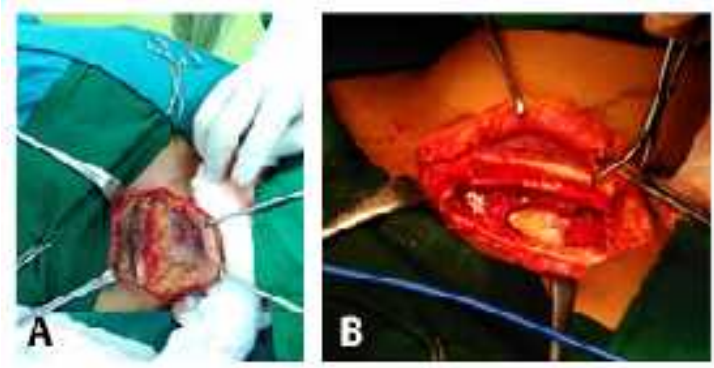

Figure 3. Identification of clavicule (A), extraction of anterior medial third of clavicule using fan boor (B).

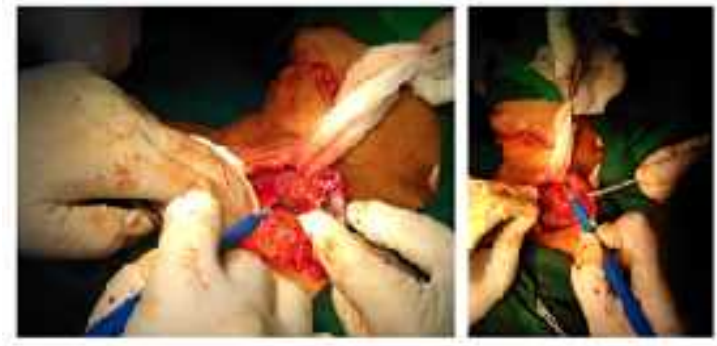

Figure 4. Clavicule was tunneled into mandible, under the skin. Sternocleidomastoid muscle as a pedicle.
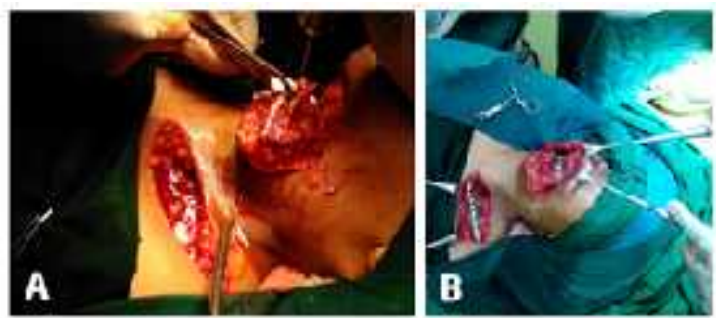

Figure 5. Place the clavicle into mandible (A), plating on mandible and clavicle (B).

Post surgery condition was uneventful. The patient was given a gradual diet from liquid to solid meal. Three days after surgery, the flap was still vital, drain was minimal which indicated to be removed. The patient was discharged on POD 7 and was planned to visit the outpatient clinic every 3-5 days until POD 14. Finally, we remove the suture, operation scar is good, and the flap is vital during one year follow up (figure 6).

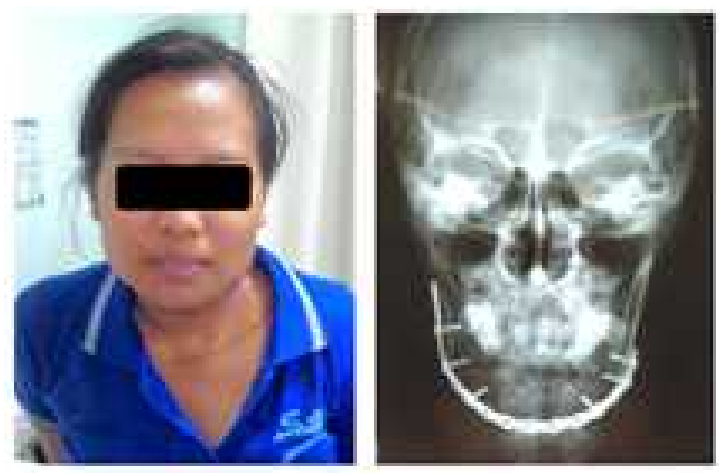

Figure 6. Clinical picture after the operation.

\section{DISCUSSION}

This case report showed an uncommon case, a woman with broken previously reconstructed plate due to trauma. This patient had a history of ameoblastoma. Odontogenic lesion develop during or after formation of teeth. ${ }^{7}$ Most odontogenic mandibular lesions are benign, but some may exhibit aggressive and destructive behavior locally. ${ }^{8}$ Previously, after the tumor been resected, she had free fibular graft which is the "first line" choice for mandibular reconstruction. ${ }^{4}$

The option for choosing the flap method is based on donor site morbidity. 3,4 
So we decided to do a pedicled flap which has a advantage over graft of its vascularization. In pedicled flap, we do not have to do a microvascular surgery to anastomose the vessel to the vessel in recepient site, which is needed in free flap. Pedicled myoosseus have the advantages of ease of flap harvest, relatively short operative time, improved healing, and decreased infection rate. Their disadvantages include limited amount of bone for grafting and limited maneuverability of the bone. ${ }^{1}$ The flap itself have a different type with graft which have its own blood supply from the donor site, compared with graft which relies on growth of new blood vessel from recepient site.

Sternocleidomastoid myoosseus flap in one of the pedicled flap available for head and neck surgery. This technique uses muscle and bone for reconstruction. After tumor resection, the clavicle is measured to obtain the desired segment to fill the mandibular defect. The clavicle that is harvested must include its medial portion and at least two thirds of the lateral clavicular body. ${ }^{1}$ Once the sternocleidomastoid muscle is dissected, preserving the clavicular attachment, the thyrocervical trunk, its blood supply, is identified and transected. The superior thyroid trunk is preserved superiorly, as is the spinal accessory nerve. Once the clavicle is released from all its attachment except for the sternocleidomastoid, it is rotated on the muscular pedicle across the midline into the defect and fixated with conventional bone fixation systems. ${ }^{1}$

The primary problem with this type of flap is the blood supply to the SCM muscle. The flap as described is a superior based one, which has the occipital artery as the major supply to the superior aspect of the muscle only. ${ }^{1}$ Thus the skin component of the flap is unreliable. But in this case, we didn't use any skin flap, since she did not have any skin defect, so it does not matter. Other disadvantages include the exposure of the great vessels of the neck after mobilization and a resulting contour deformity of the neck. But, we try to overcome this problem by using only the anterior medial third of left clavicle (not all part), and place it to the mandible. As we made two separated incision (first over submandible and second over left clavicle), we did the flap under the skin surface by tunneling it to mandible. The sternocleidomastoid muscle works as a pedicle for supplying the vessel to the clavicle. After flap, we use plate in both mandible and left clavicle to strengthen them. This flap is a rapid, technically easy flap to elevate for one-stage immediate reconstruction of oromandibular defects also provide increased resistance to infection. ${ }^{1}$

\section{CONCLUSION}

Sternocleidomastoid - clavicle myoosseus flap is practical and safe procedure, which can be used as alternative option in ameloblastoma reconstruction.

\section{REFERENCES}

1. Garajei A, Arabkheradmand A, Motamedi MHK, et al. Reconstruction of the Face Following Cancer Ablation. In: Motamedi MHK, editor. A Textbook of Advanced Oral and Maxillofacial Surgery Volume 2. Croatia: Intech Publications; 2015.

2. Carter LL, editor. Principles of Reconstructive Surgery in Africa. Africa: PAACS Publication: 2013.

3. Hanasono MM. Reconstructive Surgery for Head and Neck Cancer Patients. Advances in Medicine. 2014;2014:795483. 
4. Lin $\mathrm{P}-\mathrm{Y}$, Lin $\mathrm{KC}$, Jeng S-F. Oromandibular Reconstruction: The History, Operative Options and Strategies, and Our Experience. ISRN Surgery. 2011;2011:824251.

5. Pogrel MA, Schmidt B, Robertson CG. Clinical pathology: Odontogenic and Nonodontogenic Tumors od the Jaws. In: Booth PW, Schendel SA, Hausamen JE, editors. Maxillofacial pathology. Edinburgh: Churchill Livingstone; 2006. p. 490.

6. Scholl RJ, Kellett HM, Neumann DP, et al. Cyst and cytic lesions of the mandible: clinical and radiologichistopathologic review. Radiographics. 1999:19:1107-24.

7. Goaz PW, White SC. Oral radiology: Principles and Interpretation. 3rd Edition. St Louis: Mosby-Year Book; 1994. p. 398-676.

8. Weber AL. Imaging of cyst and odontogenic tumors of the jaw. Radiol Clin North Am. 1993;31:101-20. 